CĂLIN TEUTIȘAN

\title{
CONCEPTUAL CONFIGURATIONS AND INTERPRETIVE PRACTICES IN ACADEMIC LITERARY CRITICISM OF THE 1970s. LIVIU PETRESCU AND THE CRITICAL ESSENTIALISM ${ }^{1}$
}

Ever since his debut volume, Realitate și romanesc (Reality and Narrative Worlds), Liviu Petrescu was seduced by topics that engaged with ethical and/ or/versus aesthetic issues (see Petrescu 1969). The critic's discourse appeared to be rather terse, emphasizing, however, his preference for clarity of expression and for fecund interpretive approaches. On the other hand, Liviu Petrescu's hermeneutics never avoided polemical stances in relation to what he deemed to be obsolete or, in any case, "unfaithful" (to use a term preferred by Nicolae Manolescu in 1966) interpretations of literary texts. Regarding the metacritical perspective, when Liviu Petrescu adopted a critical position, he usually provided solutions in the order proposed by the author whose ideas he discussed, though not necessarily in an alternative order of interpretation. Moreover, Petrescu insisted that literary criticism did not need to exude originality. His demonstration was somewhat contradictory and ambiguous. "A very deep-rooted prejudice is that the critic should display intellectual 'originality'; in his comments, he is demanded to use 'personal' notions and concepts, not ideas 'borrowed' from other authors. Such a position seems to us to be deeply a-cultural", he stated, with undisguised verve (Petrescu 1973, p. 8). What Petrescu proposed instead, in keeping with his plea for cultural influences and against argument structures based "exclusively on personal ideas" was, however, even more personal, if not downright abysmal:

"The field of manifestation for the personality of the critic is - we claim - the field of perceptions! One critic always differs from another by what impresses him most vividly in a text and will later become the keystone of his entire critical construction. Only this primary impression is acutely personal; where that is missing, the critic is actually no longer a critic, but... a gabber. However flashily he might be spinning the hammer of value judgments!" (ibidem, p. 9).

Therefore, the battle of "personalism" and "originality" in literary criticism takes place in the realm of notions and concepts versus impression (primary). The

\footnotetext{
${ }^{1}$ A first version of this study is published, in Romanian, in Sanda Cordoș (ed.), Spiritul critic la Liviu Petrescu, Cluj-Napoca, Editura Limes, 2011, p. 158-165. A revised version of the study is published, also in Romanian, in Călin Teutișan, Scenarii ale criticii. Protagoniști, metode, interpretări, Cluj-Napoca, Editura Școala Ardeleană, 2021, p. 53-72. This is the first internationally available rendition.
} 
former are necessary for the conceptual grammaticalization of interpretation, but are of secondary importance as regards the hermeneutic effort and its success. The latter, however, is essential for understanding the truth of the work, its aesthetic ontology. The original impression would correspond, in the practice of interpretation, to that level in the practice of artistic creation that Ioana Em. Petrescu referred to, in 1981, with a much more expressive phrase, namely the pure intuition of form (Petrescu 2015, p. 42). Liviu Petrescu did not change his mind about impression (though the notion was no longer used in the critic's subsequent theorizations), and his interpretive practice did not explicitly, but only obliquely operationalize it, sometimes allowing the impression to be barely guessed behind some options for certain topics or reasons commented by the author in relation to various literary texts. In Ioana Em. Petrescu's view, on the other hand, the pure intuition of form was to become, as I have shown elsewhere, the centre of a systemic model for acquiring knowledge and understanding of the ontology of artistic creation, whose justifying value could be found in the metaphysics of aesthetic construction.

Secondly, in 1973, the still young critic Liviu Petrescu made a plea for impressionism, a plea that was nonetheless concealed in the folds of the thesis about the need for conceptual borrowings. Of course, this is not a matter of Călinescuinspired impressionism. On the other hand, the thesis that critical influences ought to be embraced was also the expression of a theoretical drive, already visible in the articles written by the Cluj-based professor, emphasizing the need to use previous models, systems and interpretive acts as stepping stones for the new critical discourse, which could thus settle itself more appropriately in the realms of analysis and synthesis. The theory of conceptual anti-originality did not, however, prevent Liviu Petrescu from launching a discussion on Tudor Vianu, by massively accumulating (!) some opinions of contemporary critics who reproached Vianu precisely for his lack of originality, using phrases such as "Tudor Vianu is never "the first" (the quote comes from Nicolae Manolescu, who stated that in an article he published in the Contemporanul review in 1966); or: Vianu's "aesthetic system" is "an 'eclectic' product", made up of "materials that have already been used elsewhere before" (the ideas and quoted terms come from Adrian Marino, who first expressed them in an article printed in the Cronica review) and so on (see Petrescu 1973, p. 57). Liviu Petrescu "saved" Vianu in extremis (and only half convinced) by claiming that the aesthetics scholar had embraced an "inner action" (ibidem, p. 58) when he elaborated an explanatory system of the systems he studied, engaging in a meta- activity of the critical spirit and pursuing the idea of creation in itself, rather than that of original creation.

So which is the critical model that the author assumed or acknowledged? In the subchapter On "the two selves" from the first chapter of Scriitori români și străini (Romanian and Foreign Writers), Liviu Petrescu announced a debate on the "new criticism." He referred, obviously, to the new French criticism, in full swing at the time, and not to the formalist American New Criticism of the 1940s and 1950s. Was this the claim of a methodological critical identity, or just a topical reference? 
Let us examine the author's definitions and conclusions, briefly communicated at the beginning of the passage:

"The merit of the 'new criticism' (of 'interpretation criticism', if I were to use a more appropriate term) lies in being familiar with the idea that $[\ldots]$ the personality of a writer will not be reduced to a formula, for the simple reason that it is not $[\ldots]$ a unitary phenomenon; on the contrary, the analysis reveals a much more complex reality, composed [...] of an everyday 'I' (the 'self' that manifests itself in the field of immediate existence, social relations, the biographical) and [...] an intermittent 'I', which surfaces only at moments of maximum creative concentration. Consequently, biographical information - cultivated with such fervour in traditional criticism - was no longer recognized as having any explanatory value" (ibidem, p. 11-12).

We can distinguish here the cultural political principle that underlies the controversy of new criticism in relation to old criticism, namely the rejection of biography as a model of explaining aesthetics. For Liviu Petrescu, the political aspect is secondary, emerging as the practical effect of the dissociation of "selves". However, even if we remain in the field of the practical effects produced by Nouvelle critique, the most important of these was described, in the articles of that period, as the "exhaustive description" of the "basic units" of the text ${ }^{2}$.

Regarding the interpretive practice, Roland Barthes's dissociations in Criticism and Truth between the science of literature and literary criticism (Barthes 1966, Barthes 1980) explain more about the field in which Liviu Petrescu wished to enter: obviously, this was the science of literature. What did it look like and what were its explicit stakes? We find them in the same volume, Scriitori români şi străini, in the subchapter entitled On the "essay". The fragment again includes a discussion related to new criticism. It distinguishes between study and essay, i.e. between scientific positivism (factual) and philosophical speculation, the latter being interested in "general essences" (Petrescu 1973, p. 15-17). Emulating Barthes's Criticism and Truth (and the Frenchman's views on the science of literature), but also invoking Genette's "pure criticism", which also aimed to "transcend the individual literary fact, and aspired towards "general essences" (ibidem), Liviu Petrescu advocated, in several sentences, the "cultural necessity of the essay", which "is the most appropriate literary form through which contemporary spirituality is expressed" (ibidem). Therefore, in the descent of French new criticism, Petrescu saw himself as an essayist, oriented towards the essences of literature and practising a "pure" criticism, of "metaphysical" speculation.

At first sight, at least, Liviu Petrescu respected his critical and methodological program, assumed with vigor and firmness in the essays mentioned above. His first volume, Realitate și romanesc, suggested that the "essences" of literariness should

\footnotetext{
${ }^{2}$ See Funt 1968, p. 329: "Thus these critics [...] are united in their view that criticism should be adressed first and above all to the internal structure of the work in question in attempting in one way or another to accomplish an exhaustive description of its basic unities and their organisation, before endeavouring to relate the work to the world external to it".
} 
be the objects of interpretation. These he identified largely in canonical works: the beautiful (in works by Duiliu Zamfirescu and Gib. I. Mihăescu), melancholy (in Mateiu Caragiale's texts), love (in the novels of Liviu Rebreanu and Camil Petrescu), conscience (in the case of Hortensia Papadat-Bengescu), moral instinct (Anton Holban), reality (in the final considerations, which concluded the volume). Problems pertaining to the ethicallaesthetic binomial became visible in the first critical statements, dedicated to Duiliu Zamfirescu. Petrescu's thesis was that "the writer aligns himself $[\ldots]$ with a general reaction at the time, directed against the naturalist current and the positivist spirit, which had begun to prevail in practical life", the novelist proposing instead "the solution of aestheticizing postnaturalist literature," in the sense that "he recommended a total annihilation - through a conscious effort - of both 'individual' and 'social' nature, placing one's whole conduct, including practical life, under the sign of Beauty" (Petrescu 1969, p. 22-23).

The ethical side of Zamfirescu's literature was revealed to Liviu Petrescu in terms of the author's anti-naturalist criticism, which "can also be considered as a first statement in the Romanian novel of consciousness, [...] which tries first of all to imprint some truth into our existence" (ibidem, p. 42, emphasis added). This happened because of the aesthetic/aestheticizing drive, as a neo-romantic reflection of the literary imaginary. Therefore, the critic's conclusion based on the novelistic texts of the postnaturalist writer seemed to be that the "true character of existence" was equivalent to aesthetics. Another issue of the "aesthetic ideal" was followed in the comments on Mateiu Caragiale's literature, where Liviu Petrescu remarked that all the author's characters were, in fact, "a variant of the same type", i.e. of the dandy, with a "moral physiognomy" dominated by melancholy (ibidem, p. 45, 54). Similarly, "aesthetic aspirations" (ibidem, p. 235) also characterized the protagonist of Gib Mihăescu's Donna Alba. And while the fundamental topic of interpretation was aesthetics in the case of Duiliu Zamfirescu, Gib Mihăescu and Mateiu Caragiale, ethics prevailed in the case of Liviu Rebreanu, through the analysis of the destiny of a character like Apostol Bologa. To a certain extent, the same happened when it came to judging the "relations between the physical and the moral" in Hortensia Papadat-Bengescu's work, where the critic discovered, in the author's theory about the "spiritual body", a phenomenological substratum underlying the assertion of the "substantiality of our soul" (ibidem, p. 121). Hortensia Papadat-Bengescu had thus opened the way for the Husserlian "substantialism" of Camil Petrescu, which Liviu Petrescu used, including by invoking the phenomenological concept of essence, in a discussion on the possibilities offered by phenomenology in the construction of novelistic characters, but also on its limits in the confrontation with the "real reality" (within fiction, of course) of the object. We are talking here about the subject and the erotic object, since the topic of discussion was love and jealousy. The comments on Anton Holban were very original, advancing the thesis of the affective instinctuality of the character Sandu. Up to Liviu Petrescu, literary critics had glossed on the subject of the character's psychology, regarding it as a narrative tactic of the novel and emphasizing, therefore, an 
aesthetic thesis. The theory of affective instinct, generating "moral weaknesses" which led to flaws of conduct and errors of conscience, pushed the analysis (and its findings) into the field of ethics.

The ethical propensity, but also the category of the tragic are brought back into discussion in the Dostoievski micro-monograph. The critical method is "regressiveprogressive" (in Liviu Petrescu's terms) and this is how he appropriates Sartre's existential psychoanalysis, from Being and Nothingness, 1943). It reveals the way in which the effects of the (Dostoevsky) doctrine of organicity are always rivalled by the principle of disorder, with tragic results as regards the ontology of the characters (Petrescu 1971, p. 35, 96, 106). Yet the book most faithful to Liviu Petrescu's critical project, until 1992 (the year when the first edition of Poetica postmodernismului was published), is Romanul conditiei umane (The Novel of the Human Condition). Here we find, again, a number of approaches to the novels of Dostoevsky (in six of the subchapters of the volume), as well as comments on the works of authors such as Tolstoy, Kafka, Malraux, Sartre, Joyce, Thomas Mann, Proust, Camus and Hortensia Papadat-Bengescu. In the introductory chapter, Hypostases of the Absolute, we discover both the structure of the theme ("in its dynamics, the theme of the 'human condition' tends to fit [...] into a scheme of circularity") and its history, divided into three ages: Greek classicism, mannerism and romanticism (Petrescu 1979, p. 11-15). Everything is examined from a postexistentialist perspective, relying on the conflicting tension between "the eternal, absolute thirst of the human spirit, on the one hand, and the various limitations or restrictions it has to put up with, on the other" (ibidem, p. 229). This conflict entails two aspects: a metaphysical one, concerning the "confrontations with the [divine] Law" (however it might appear in the literary text), and an ontological one, regarding the limitations inherent in the "fundamental categories of existence: space, time and individuation" (ibidem, p. 230). More than the monograph of a literary theme, Romanul condiției umane is the monograph of an essence (an ontological essence, here), of the kind mentioned in Genette's theories, an essence that is systematically explored in its historical and aesthetic dimensions. Petrescu's theoretical and systematizing drive is clearly at work here, as is his "essentializing" penchant from his 1992 book, Vârstele romanului (The Ages of the Novel), especially as it came out in its second, augmented version in 1996, Poetica postmodernismului (The Poetics of Postmodernism) - Petrescu 1996.

In his last volume, Studii transilvane (Transylvanian Studies), Liviu Petrescu returned to the ethical dimension through the very subtitle of the book: Epic și etic in proza transilvăneană (Narrative and Ethics in Transylvanian Prose). Several topics are of seminal importance in the studies included here. First, the topic of realism in the Transylvanian novel, seen in three stages: popular realism (in texts by Ioan Slavici), mythical realism (in works by Liviu Rebreanu) and the so-called textualist realism, in more recent works of the 1980s (Petrescu 1997, p. 7-8). The identification of Enlightenment roots in Slavici's social philosophy and, in the same author's works, of a Nietzschean perspective reflected in the theme of power 
revealed the critic's fresh, less conventional view of the classical prose writer. Other insightful comments spoke of the fascination with the epic in Pavel Dan's short stories, the contradictory and tense ethical codes in the works of Titus Popovici, the ontological and social dilemmas of Alexandru Ivasiuc, the Nietzscheanism of Nicolae Breban, and the obsession with death in Augustin Buzura's novels. All this was to resemanticize an older critical image, which, impervious to the currents of thought of the modern era, has approached the Transylvanian narratives from the perspective of "character construction" (ibidem, p. 9), modelled exclusively on primitive, simplistic ethical categories.

In the second part of the book, dedicated to mythical realism, the fragment about the "realism of essences" in the works of Liviu Rebreanu, oriented towards "capturing the totality of being" by following a "deep, Dionysian vocation" (ibidem, p. 106), recalls the principles of French new criticism, which had been postulated, in a different text, by the author himself. Another significant analysis is that of the fairy-tale structure of Caron's Boat (Luntrea lui Caron), as well as the discussion on D. R. Popescu's expressionism, the "consciousness of the characters" in Sorin Titel's texts, the soteriology in the mythical chronotope of Tudor Dumitru Savu, the "ontology of the void" in the works of Aurel Dragoș Munteanu or the aestheticizing language of Alexandru Vlad.

In Studii transilvane, Liviu Petrescu was more of a literary critic than a literary historian, although he proposed, as can be seen from all the above examples, a historical vision of the thematic models of realism in the Transylvanian Romanian novel of the twentieth century. Yet such historical landscapes did not concern the systemic evolution of literature, or literature as a system, but remained an external history of it, based on individual aesthetic events that highlighted the peaks of literary evolution, but no so much its nature as a living organism. What prevails is the thematic analysis of the imaginary, rather than the historical dialectic of the evolution of the literary system, which becomes a by-product of interpretation, a pretext for the broad development of critical commentary on artistic objects themselves.

Finally, Liviu Petrescu best found his "voice" in the volume Poetica postmodernismului (The Poetics of Postmodernism), where the critic and theorist seemed to be the least distanced from his object, as well as the most empathetic in relation to it, compared to his other volumes. "The demon of theory" - to use a famous term coined by Antoine Compagnon in 1998 - seemed to be a good companion for Liviu Petrescu here. Poetica postmodernismului rested on significant cumulative re-systematizations and, in certain sections, on polemical positions in relation to existing modernist and postmodernist theories. The book remains, in equal measure, one of the significant theoretical contributions of its decade in the Romanian cultural space, as well as a defining work for the portrait of Liviu Petrescu, the critic. 


\section{BIBLIOGRAPHICAL ABBREVIATIONS}

Barthes 1966 = Roland Barthes, Critique et vérité. Essai, Paris, Seuil, 1966.

Barthes 1980 = Roland Barthes et alii, Pentru o teorie a textului. Antologie ,Tel Quel” 1960-1971.

Edited with introductory study and translation by Adriana Babeți și Delia Șepețean-Vasiliu,

București, Editura Univers, 1980.

Funt 1968 = David Funt, Roland Barthes and the Nouvelle Critique, in "The Journal of Aesthetics and Art Criticism", 1968, vol. 26, no. 3, p. 329-340.

Petrescu 1969 = Liviu Petrescu, Realitate și romanesc, București, Editura Tineretului, 1969.

Petrescu 1971 = Liviu Petrescu, Dostoievski, Cluj-Napoca, Editura Dacia, 1971.

Petrescu 1973 = Liviu Petrescu, Scriitori români și străini, Cluj-Napoca, Dacia, 1973.

Petrescu 1979 = Liviu Petrescu, Romanul condiției umane, București, Minerva, 1979.

Petrescu 1996 = Liviu Petrescu, Poetica postmodernismului, Pitești, Paralela 45, 1996.

Petrescu 1997 = Liviu Petrescu, Studii transilvane, București, Viitorul românesc, 1997.

Petrescu 2015 = Ioana Em Petrescu, Configuraţii. Edited with preface and notes by Ioana Bot, Cluj-

Napoca, Editura Casa Cărţii de Știinţă, 2015.

\section{CONCEPTUAL CONFIGURATIONS AND INTERPRETIVE PRACTICES IN THE ACADEMIC LITERARY CRITICISM OF THE '70s. LIVIU PETRESCU AND CRITICAL ESSENTIALISM}

(Abstract)

The speculative-philosophical tendency to identify the "general essences" of the aesthetic phenomenon and its ethical stakes confer the specificity of Liviu Petrescu's critical perspective. The critic aims not so much at the systemic evolution of literature, or literature as a system, but at its external history, based on individual aesthetic events, which reveals a number of glorious moments of the literary, but less its nature as a living organism in full transformation. What prevails is the thematic analysis of the imaginary, rather than the historical dialectic of the evolution of the literary system, which becomes a by-product of interpretation.

Cuvinte-cheie: critica literară universitară, Liviu Petrescu, esenţialism critic, interpretare etică/estetică, noua critică franceză.

Keywords: academic literary criticism, Liviu Petrescu, critical essentialism, ethical/aesthetic interpretation, French new criticism.

Institutul de Lingvistică și Istorie Literară „Sextil Pușcariu” al Academiei Române

Cluj-Napoca, str. E. Racoviţă, 21 cteutisan@yahoo.com 